\title{
Assessing phytotoxicity and accumulation of trace elements to Lactuca sativa of a contaminated shooting range soil
}

Jurate Cesynaite

Vytautas Magnus university

Marius Praspaliauskas

Lithuanian Energy Institute: Lietuvos energetikos institutas

Gintare Sujetoviene ( $\nabla$ gintare.sujetoviene@vdu.It )

Vytautas Magnus University

\section{Research Article}

Keywords: Metal contamination, Shooting range, Lettuce, Lead, Ecotoxicity

Posted Date: March 15th, 2021

DOI: https://doi.org/10.21203/rs.3.rs-231674/v2

License: (c) (i) This work is licensed under a Creative Commons Attribution 4.0 International License.

Read Full License 


\section{Abstract}

Shooting range soil contamination with heavy metals is a common problem around the world. Usually, lead is the primary contaminant in the shooting ranges. Extreme concentrations of trace elements create a toxic living environment for various plants. The purpose of this study was to evaluate the effect on lettuce (Lactuca sativa L.) grown in contaminated shooting range soil. The results showed that physiological parameters root elongation, shoot length and fresh biomass per plant were negatively affected, especially in the most contaminated site in the shooting range. At the most contaminated shooting range site shoots accumulated higher concentrations of $\mathrm{Ni}$ and $\mathrm{Zn}$, roots $-\mathrm{Cu}, \mathrm{Ni}$, and $\mathrm{Zn}$. The roots of plants grown in the most contaminated soil accumulated significantly higher concentrations of $\mathrm{Cu}, \mathrm{Ni}$, and $\mathrm{Sb}$ than the reference and accumulation of $\mathrm{Cu}, \mathrm{Fe}, \mathrm{Mn}, \mathrm{Ni}, \mathrm{Sb}$ and $\mathrm{Zn}$ in the roots of the plants grown in the most contaminated site was higher compared to shoots. Bioaccumulation factor of $\mathrm{Cu}$ and $\mathrm{Ni}$ in plants from the most contaminated site was significantly higher than the reference. Metals absorbed by L. sativa were accumulated in root and lower metal translocation in shoots was determined, except for Mn.

\section{Introduction}

Shooting ranges pose an environmental concern due to their contamination with trace elements (Mannine and Tanskanen 1993). The soil of shooting ranges is typically contaminated with lead (Pb), copper $(\mathrm{Cu})$, antimony $(\mathrm{Hg})$, arsenic (As), nickel (Ni), zinc ( $\mathrm{Zn})$, and silver $(\mathrm{Ag})$ because these elements are components of the bullets used for shooting. Lead is the primary contaminant in the shooting range soil - up to $150000 \mathrm{mg} \mathrm{kg}^{-1}$ concentrations of $\mathrm{Pb}$ are reported in the soil of shooting ranges (Sanderson et al. 2014; Barker et al. 2020). Ammunition mostly contains $\mathrm{Pb}$ ( 80\% bullet mass) and smaller traces of $\mathrm{As}, \mathrm{Sb}, \mathrm{Cd}, \mathrm{Cu}, \mathrm{Ni}, \mathrm{Mn}$, and $\mathrm{Zn}$. Cartridges and cases consist mostly of $\mathrm{Zn}$ and Ni (Urrutia-Goyes et al. 2017). Antimony is used as a hardening material and constitutes $1-2 \%$ of a bullet core (Sanderson et al. 2018). The main component of the bullet jacket usually is $\mathrm{Cu} \sim 89-95 \%$ (Moon et al. 2011). Aside from $\mathrm{Pb}$ smaller amounts of $\mathrm{As}, \mathrm{Cd}, \mathrm{Sb}$, and $\mathrm{Mn}$ are used in used in the manufacture of bullets (Fayiga and Saha 2016).

These contaminants in the shooting range soils are toxic to plants, soil biota, groundwater, and animals (Ma 1989; Carreras et al. 2009; Ahmad and Ashraf 2012; Siebielec and Chaney 2012; Sanderson et al. 2014; Ogawa et al. 2015; Rodríguez-Seijo et al. 2016; Dinake et al. 2018; Johnsen and Aaneby 2019). Lead is the main contaminant in the shooting range soils (Lewis et al. 2001). The mobility of $\mathrm{Pb}$ in the ranges strongly depends on soil $\mathrm{pH}$. Mobile forms of $\mathrm{Pb}$ can result in contamination of surface water and underground. Research has shown the presence of elevated concentrations of $\mathrm{Pb}$ in flora growing in nearby shooting ranges (Fayiga and Saha 2016). Due to extreme Pb concentrations of in soil, seed germination, the uptake of nutrient ( $\mathrm{Na}, \mathrm{Ca}, \mathrm{K}, \mathrm{P}, \mathrm{Mg}, \mathrm{Zn}, \mathrm{Fe}, \mathrm{Cu})$, chlorophyll content, plant growth, biomass decreased (Hadi and Aziz 2015; Gul et al. 2020). 
Some heavy metals are essential for plant growth, but at high concentrations, they become toxic (e.g., Co, $\mathrm{Cu}, \mathrm{Fe}, \mathrm{Mn}, \mathrm{Zn}$ ), while others (e.g., $\mathrm{Cd}, \mathrm{Pb}, \mathrm{Hg}$ ) are toxic even at low concentrations because they have no known physiological functions in plants (Boquete et al. 2021). In the early stage of plant development, the most sensitive indicator of contamination is seed germination. If the contaminant does not reach the embryo, the germination rate might not be affected. At lower concentrations, heavy metals can even stimulate germination (Moreira et al. 2020). Essential elements create adverse effects on plants only at high doses (Ullah and Muhammad 2020). For example, Cu is considered a micronutrient for plants, but at induced Cu stress, plants suffer leaf chloroses, growth retardation, and exposure to $\mathrm{Cu}$ leads to oxidative stress (Yadav 2010). Non-essential elements, such as lead, are very toxic elements for plants. Lead inhibits plant growth, disrupts nutrient consumption, and alters metabolism (Ashraf et al. 2020). The uptake and accumulation of lead vary with plant species and the concentration of this element in the environment (Ashraf et al. 2020). Exposed to lead stress, plants exhibit symptoms of poisoning (cytomembrane permeability, disturbance of enzyme activity, mitotic obstruction, DNA damage, changes in physiological processes) (Duan et al. 2020). The plants permanently growing in contaminated sites accumulate large amounts of heavy metals in their tissues (Rehman et al. 2021).

The biomonitoring tests with animals or plants to determine and compare the toxicity of contaminated soils are as possibility to evaluate detrimental effects on the environment. To our knowledge, little scientific research has been conducted on the environmental impact of contaminated soils from these sectors despite the attempts to use the plants for their phytoremediation abilities (Rodríguez-Seijo et al. 2016) or testing amendments for remediation (Ahmad et al. 2012; Siebielec and Chaney 2012). The objective of the study is to evaluate potential phytotoxicity and trace elements accumulation in Lactuca sativa exposed to shooting range soil.

\section{Materials And Methods}

Study site

Soil samples were collected from the shooting range located in Alytus, Lithuania ( $54^{\circ} 23^{\prime} 48.1^{\prime \prime} \mathrm{N}$, $\left.24^{\circ} 2^{\prime} 41.3^{\prime \prime} \mathrm{E}\right)$. The shooting range was opened in 1957 . Since then, it has been used mostly seasonally (April - July). Only small-bore (.22 LR caliber) guns are used in this shooting range. The area of the range is about $400 \mathrm{~m}^{2}$, and about $320 \mathrm{~m}^{2}$ of it is mostly overgrown by grasses. The range consists of 6 shooting positions, and the length of the shooting area is $50 \mathrm{~m}$ with two target lines at 25 and $50 \mathrm{~m}$.

Soil sampling and chemical analyses

Soil samples were collected according to distance from the shooting positions to the target lines at $25 \mathrm{~m}$ and $50 \mathrm{~m}$. Soil samples were collected 5, 20,30 and $45 \mathrm{~m}$ away from the shooting positions. At each representing site, 5 sub-samples of surface soil were collected and constituted a composite sample. Two shooting range areas were chosen: to represent a less contaminated shooting range site $(5-30 \mathrm{~m})$ and a more contaminated shooting range site $(45 \mathrm{~m})$. The reference area was selected as a grassland site in the 
relatively unpolluted area $\left(54^{\circ} 25^{\prime} 42.0^{\prime \prime} \mathrm{N}, 24^{\circ} 14^{\prime} 04.2^{\prime \prime} \mathrm{E}\right)$ and referred to as a reference soil. Soil samples were taken from the upper layer of surface soil $(10-20 \mathrm{~cm})$ after removing about $2 \mathrm{~cm}$ of soil surface layer. Samples were mixed and homogenized and stored at $4^{\circ} \mathrm{C}$ until analysis.

For chemical analysis, soil was sieved to $2 \mathrm{~mm}$ and oven dried at $60^{\circ} \mathrm{C}$ for $48 \mathrm{~h}$. Soil pH was measured potentiometrically in suspension of soil:water ratio of 1:5 using pH meter (inoLab 720, WTW). Total soil organic matter content was determined by loss on the ignition method. The bulk density of soil was determined by pouring air-dried soil samples in a measured cylinder.

Two replicates of samples ( $0.5 \mathrm{~g}$ of dry soil) were digested in $8 \mathrm{~mL}$ of $\mathrm{HCl}, 5 \mathrm{~mL}$ of $\mathrm{HNO}_{3}, 5 \mathrm{~mL}$ of $\mathrm{HBr}$, and $3 \mathrm{~mL}$ of $\mathrm{HF}$ in the Teflon vessels using a microwave digestion system (Milestone Ethos One, Italy). After mineralization samples were diluted with purified water to $50 \mathrm{~mL}$. The total concentrations $\left(\mathrm{mg} \mathrm{kg}^{-}\right.$ ${ }^{1}$ ) of elements ( $\mathrm{Pb}, \mathrm{Cu}, \mathrm{Fe}, \mathrm{Mn}, \mathrm{Ni}, \mathrm{Sb}$ and $\mathrm{Zn}$ ) were determined using inductively coupled plasma optical emission spectroscopy (ICP-OES, Perkin-Elmer, Optima 8000). The concentrations of selected elements were measured at wavelengths: $220.353 \mathrm{~nm}, 327.393 \mathrm{~nm}, 238.204 \mathrm{~nm}, 257.610 \mathrm{~nm}, 231.604 \mathrm{~nm}$, $206.836 \mathrm{~nm}$ and $20.6200 \mathrm{~nm}$, respectively. Calibrations of trace elements were made by analysing standard (Multi-Element Quality Control Standard, 21 Elements, Perkin Elmer) solutions in four replicates. Precision of analysis was estimated by the coefficient of linear correlation and was found to be not less than 0.999 for all measured elements. At the beginning of selected elements, analysis of certified reference material (CRM Metals in Soil (SQC001), Sigma - Aldrich) was made, and the reproducibility was found in range $\pm 10 \%$ within the certificated values of all selected elements. During analysis every ten measurements was made QC, when the selected value exceed the established limits recalibration was performed.

\section{Plant toxicity study}

The contaminated shooting range soil was used to evaluate the toxicity of heavy metals in the soils. Lettuce (Lactuca sativa L.) has been chosen for this study as a reference species to characterize plant response in pot experiments. The selection of this species was based on its relevance to phytotoxic investigations, as it is known as a bioindicator species of heavy metals. It is also considered an accumulator of heavy metals $(\mathrm{Cd}, \mathrm{Pb}, \mathrm{Zn})$. It is proved that physiological changes of $L$. sativa reflected the quality and characteristics of the environment (Moreira et al. 2020). This plant is amenable to testing in the laboratory and grows relatively fast. Research shows that it can survive extreme conditions in shooting range soils heavily contaminated with heavy metals. We consider it suitable to evaluate potential shooting range soil toxicity to plants. The phytotoxicity test was carried out according to the OECD guidelines for the testing of chemicals (OECD/OCDE 208 2006). $200 \mathrm{~g}$ of each homogenized and sieved $(2 \mathrm{~mm})$ soil was placed in pots, and 9 lettuce seeds were evenly sown into the soil. The test soil was hydrated, and distilled water was added daily to maintain $50 \%$ water holding capacity of the soil. The plants were grown for 21 days in a climate chamber where the average temperature was $20 \pm 2^{\circ} \mathrm{C}$ and relative humidity was $60 \%$. An average photon flux density was $180-200 \mu \mathrm{mol} \mathrm{m}{ }^{-2}$. Three replicates (pots) of all treatments were made. 
Seed germination was observed after 7 days. The germination rate (\%) was calculated as the number of seeds sprouted divided by the total number of seeds and multiplied by 100 . At the end of the experiment, seedlings were harvested, and the plant fresh weight was assessed. The plant height and root length were measured. Subsequently, shoots and roots were separated and dried at $60^{\circ} \mathrm{C}$ in an oven until a constant weight was obtained. Three sub-samples of soil and plant were used for the analytical analyses $(n=3)$.

For heavy metal analysis, dry material was homogenized (Retsch HM400, Germany). Two replicates of homogenized material of samples were followed by acid digestion in $65 \% \mathrm{HNO}_{3}$ and $30 \% \mathrm{HF}(\mathrm{v} / \mathrm{v}=8 / 2)$ using a high-pressure microwave digestion system (Milestone ETHOS One, Italy). Samples were diluted to $45 \mathrm{~mL}$ with purified water. After that, the concentration of elements ( $\mathrm{Pb}, \mathrm{Cu}, \mathrm{Fe}, \mathrm{Mn}, \mathrm{Ni}, \mathrm{Sb}$ and $\mathrm{Zn}$ ) were determined using inductively coupled plasma optical emission spectroscopy (ICP-OES, Perkin-Elmer, Optima 8000). Selected elements were measured at the same wavelength as soil samples. Calibrations of trace elements were also made by analysing standard (Multi-Element Quality Control Standard, 21 Elements, Perkin Elmer) solutions in four replicates. Precision of analysis was also estimated by the coefficient of linear correlation and was found to be not less than 0.999 for all measured elements. At the beginning of selected elements, analysis of the plant reference material (BCR-129, hay powder) was made. The reproducibility was found in range $\pm 10 \%$ within the certificated value of $\mathrm{Zn}$ and the other elements selected in CRM: $\mathrm{Cu}, \mathrm{Fe}, \mathrm{Mn}$. During analysis every ten measurements also was made QC test, when the selected value exceed the established limits recalibration was performed. These quality control measurements ensured the reliability of the results.

Translocation factor (TF) was calculated to evaluate the ability to translocate elements from soil to root and from root to shoot. TF was calculated by the method suggested by Sun et al. (2017) from soil to root (Eq. (1)) and from root to shoot (Eq. (2)).

$\mathrm{TF}_{\text {soil to root }}=\mathrm{C}_{\text {root }} / \mathrm{C}_{\text {soil }}(1)$

$\mathrm{TF}_{\text {root to shoot }}=\mathrm{C}_{\text {shoot }} / \mathrm{C}_{\text {root }}(2)$

where $\mathrm{C}_{\text {root }}$ is the content of examined element in root, $\mathrm{C}_{\text {soil }}$ - the content of examined element in soil, and $\mathrm{C}_{\text {shoot }}$ - the content of examined element in shoot.

In terms of bioaccumulation of heavy metals, we evaluated bioaccumulation factor (BF). Plants with BF above 1 are reported as hyperaccumulators (Yazdi et al. 2019). BF was calculated (Eq. (3)) by the method suggested by Midhat et al. (2019):

$\mathrm{BF}=\mathrm{C}_{\text {shoot }}\left(\mathrm{mg} \mathrm{kg}^{-1}\right) / \mathrm{C}_{\text {soil }}\left(\mathrm{mg} \mathrm{kg}^{-1}\right)(3)$

where $\mathrm{C}_{\text {shoot }}$ is the content of the element in root and $\mathrm{C}_{\text {soil }}$ - the content of a tested element in soil.

Statistical analyses 
To analyze the effects of the study area, data were grouped in three units according to the lead contamination: 1) reference soil; 2) soil from less contaminated areas (5-30 m) were combined into one forming a medium contaminated study plot, and 3 ) the heavily contaminated area $(45 \mathrm{~m})$ of the shooting range. Relationships between concentrations of trace elements and plant parameters, as well as differences between TFs and BFs of heavy metals were assessed using the Mann-Whitney $U$ test $(p<$ $0.05)$. Spearman correlation was used to identify the relationship between heavy metal concentration in soil and in the tissue of plants $(p<0.05)$. The statistical analysis was condicted by using IBM SPSS Statistics 25.

\section{Results}

The results of soil analyses show that the $\mathrm{pH}$ of the studied shooting range and control soil was close to neutral. The soil from $45 \mathrm{~m}$ distance had a significantly lower $\mathrm{pH}(\mathrm{p}<0.05$; Table 1$)$. Soil organic matter content and density did not show any significant differences compared to control $(p>0.05)$. Ammonium content in the 5-30 $\mathrm{m}$ area was significantly higher compared to control. Significantly lower phosphorus content was observed in the $45 \mathrm{~m}$ area of shooting range soil compared to control $(p<0.05)$.

Analyses of total trace element concentrations show that shooting range soil contained high concentrations of lead, with maximum contamination in the $45 \mathrm{~m}$ area of the range $\left(54560 \mathrm{mg} \mathrm{kg}^{-1}\right)$, significantly higher concentrations of lead were observed in the 5-30 and $45 \mathrm{~m}$ areas of the shooting range $(p<0.05)$. The concentration of $\mathrm{Cu}$ in the shooting range soil was lower compared to control. Fe concentration was over $8000 \mathrm{mg} \mathrm{kg}^{-1}$ in the $45 \mathrm{~m}$ area of the shooting range, but no significant differences in Fe concentration were observed. $\mathrm{Mn}$ and $\mathrm{Zn}$ concentrations in the 5-30 $\mathrm{m}$ area were lower compared to control and to $45 \mathrm{~m}(\mathrm{p}<0.05)$. Even $528.3 \mathrm{mg} \mathrm{kg}^{-1}$ concentration of $\mathrm{Sb}$ was determined from the $45 \mathrm{~m}$ area of the shooting range. The $45 \mathrm{~m}$ site was a more contaminated site than $5-30 \mathrm{~m}$ because of the higher concentration of $\mathrm{Pb}, \mathrm{Ni}, \mathrm{Sb}$, and $\mathrm{Zn}(\mathrm{p}<0.05)$.

Physiological parameters of L. sativa exposed to shooting range soil show that seed germination rate was no different between shooting range soil and control (Table 2). Plants grown in contaminated shooting range soil had significantly lower root length than the reference. The lowest roots had plants exposed to soil from the $45 \mathrm{~m}$ area $(\mathrm{p}<0.05)$. Although seed germination in plants grown in the most contaminated site was similar to the control, after a few weeks of the experiment, differences in grow were visible - the growth of the plant in the most contaminated site was retarded. Analyses of shoot length and fresh biomass clearly showed the plants exposed to the most contaminated site had significantly lower shoot length $(p<0.05)$ and fresh biomass per plant than the reference soil $(p<0.05)$.

Lettuce exposed to contaminated shooting range soil accumulated high concentrations of lead (Fig. 1). Significantly higher $\mathrm{Pb}$ concentrations were observed in shoots of plants grown in the contaminated soil compared to the reference soil, with the highest concentration being $3963 \mathrm{mg} \mathrm{kg}^{-1}$. The roots of plants grown in the soils from the shooting range accumulated significantly higher concentrations of lead compared to the reference soil. Eight times more lead was accumulated in the plants grown in soil from 
the 5-30 $\mathrm{m}$ area, and 687 times more lead was accumulated in plants grown in soil from the $45 \mathrm{~m}$ area compared to the reference soil (Fig. 2). The roots accumulated significantly more lead compared to shoots $(p<0.05)$. The roots of plants grown in the most contaminated site accumulated 10 times more lead than shoots of the same site. The statistically significant correlations between total $\mathrm{Pb}$ concentration in soil and $\mathrm{Pb}$ concentration in shoots $(r=0.97, p<0.05)$ and roots $(r=0.91, p<0.05)$ were determined.

No significant differences were determined among all heavy metal concentrations in the shoots of lettuce grown in the soil from the 5-30 m site of the range compared to reference shoots ( $p>0.05$; Fig. 2$)$. In shoots of lettuce grown in the most contaminated site of the shooting range, significantly higher $\mathrm{Cu}, \mathrm{Fe}$, $\mathrm{Mn}, \mathrm{Ni}, \mathrm{Sb}$, and $\mathrm{Zn}$ concentrations were found compared to control shoots. In shoots of plants grown in the most contaminated study site, significantly higher concentration of $\mathrm{Cu}, \mathrm{Fe}, \mathrm{Mn}, \mathrm{Sb}$, and $\mathrm{Zn}$ were observed than shoots of plants grown in soil from the $5-30 \mathrm{~m}$ area $(p<0.05)$. The roots of lettuce grown in the soil from the 5-30 $\mathrm{m}$ area of the range accumulated significantly higher concentrations of $\mathrm{Cu}, \mathrm{Fe}$, and $\mathrm{Ni}(\mathrm{p}<0.05)$ compared to the control (Fig. 2). The roots of L. sativa grown in the most contaminated range soil accumulated significantly higher concentrations of $\mathrm{Cu}, \mathrm{Fe}, \mathrm{Ni}$, and $\mathrm{Sb}$ compared to the control $(p<0.05)$. The roots of plants grown in the $5-30 \mathrm{~m}$ area soil accumulated significantly higher concentrations of $\mathrm{Cu}, \mathrm{Fe}, \mathrm{Mn}$, and $\mathrm{Zn}$ than shoots of the same plants $(\mathrm{p}<0.05$, Fig. 2). Among plants grown in the soil from the most contaminated site, significantly higher $\mathrm{Cu}, \mathrm{Fe}, \mathrm{Mn}, \mathrm{Ni}, \mathrm{Sb}$, and $\mathrm{Zn}$ concentrations were observed compared to shoots of plants grown in the soil from the same area. A significant correlation was determined between total Ni concentration in soil and Ni concentration in shoot $(r=0.97, p<0.05)$ and root $(r=0.99, p<0.05)$.

The BF values in lettuce of all sites were lower than 1 (Table 3). BF of $\mathrm{Cu}$ in plants grown in the most contaminated shooting range soil was 0.98 . It was significantly higher compared to control $(p<0.05)$. Significantly higher than control, but still relatively low $\mathrm{BFs}$ of $\mathrm{Fe}, \mathrm{Mn}, \mathrm{Ni}, \mathrm{Pb}, \mathrm{Zn}$ were also calculated in lettuce from the $45 \mathrm{~m}$ area of the shooting range $(\mathrm{p}<0.05)$. BF values of $\mathrm{Pb}$ were very low $(0.02 \mathrm{at} 5-30 \mathrm{~m}$ and 0.04 at $45 \mathrm{~m}$ ), which could be because of extremely high soil $\mathrm{Pb}$ concentrations.

The TF of soil to root of $\mathrm{Cu}, \mathrm{Fe}, \mathrm{Ni}, \mathrm{Pb}, \mathrm{Zn}$ was significantly higher than TF of root to soil in lettuce grown in the 5-30 $\mathrm{m}$ area of the range (Fig. 3). The TF of soil to root of $\mathrm{Cu}, \mathrm{Fe}, \mathrm{Ni}$, and $\mathrm{Pb}$ was significantly higher compared to TF of root to shoot in lettuces grown in shooting range soil in the $45 \mathrm{~m}$ area. $\mathrm{TF}_{\text {soil to root }}$ of $\mathrm{Cu}$ (5-30 and $45 \mathrm{~m}), \mathrm{Ni}(45 \mathrm{~m}), \mathrm{Pb}$ (5-30 and $45 \mathrm{~m})$, and $\mathrm{Zn}(5-30 \mathrm{~m})$ were above 1. A strong positive correlation between total $\mathrm{Ni}$ concentration in soil and bioconcentration factor of $\mathrm{Ni}(r=0.89, p<0.05)$ and $\mathrm{TF}_{\text {root to shoot }}(r=0.97, \mathrm{p}<0.05)$ was determined. On the contrary, a strong negative correlation was determined between total $\mathrm{Ni}$ concentration in soil and $\mathrm{TF}_{\text {shoot to root }}(r=-0.96, \mathrm{p}<0.05)$. The TF of Pb from roots to shoots significantly correlated with total soil $\mathrm{Pb}$ concentration $(r=0.90, \mathrm{p}<0.05$; Fig. 3$)$.

\section{Discussion}


In this study, basic soil analyses reflected site-specific shooting range contamination with heavy metals and changes in physicochemical soil properties. The changes in soil properties such as $\mathrm{pH}$ and organic matter can change heavy metal solubility. For example, some heavy metals have a strong attraction to soil organic matter, which means that the organic matter should be highly efficient in the sorption of heavy metals. Also, the binding of heavy metals with organic matter is a strongly $\mathrm{pH}$-dependent process (Lewińska and Karczewska 2019). Soil pH at the most contaminated shooting range soil was lower compared to control and this is in accordance with the finding when $\mathrm{pH}$ values of the full-bore military shooting ranges soil ranged from 5.6 to 8.0 (Kumarathilaka et al. 2018, Lewińska and Karczewska 2019). Changes in $\mathrm{pH}$ affect the migration and distribution of heavy metals (Zhang et al. 2018).

Phytoavailability of $\mathrm{Pb}$ is $\mathrm{pH}$-dependent. By lowering soil $\mathrm{pH}$, the availability of $\mathrm{Pb}$ could increase (Gul et al. 2020).We could conclude that other original properties of shooting range soil do not drastically change the solubility of contaminants (heavy metals) because the main soil properties discussed earlier did not change significantly, except pH (Ashworth and Alloway 2008; Lewińska and Karczewska 2019).

The major contaminant of shooting range soil was lead (from 386.37 to $54560.13 \mathrm{mg} \mathrm{kg}^{-1}$ ). Concentrations of lead in shooting range soil exceed the limit for soil Pb concentration $\left(100 \mathrm{mg} \mathrm{kg}^{-1}\right)$ in Lithuania (HN 60:2004). Similar results were reported in the studies (Rodríguez-Seijo et al. 2016; Kumarathilaka et al. 2018; Lewińska and Karczewska 2019). During our study, the plant was capable of surviving at higher $\mathrm{Pb}$ concentrations, but adverse effects on growth were visible. In general, lead as a non-essential element negatively affects root, plant growth, inhibits photosynthesis, enzymatic activities and, at very high concentrations, leads to cell death (Hadi and Aziz 2015). Total concentrations of $\mathrm{Cu}, \mathrm{Fe}$, $\mathrm{Mn}$, and $\mathrm{Ni}$ do not pose an environmental risk, as concentrations do not exceed limit concentrations (HN $60: 2004)$. However, the total concentration of Sb exceeded the concentration limit $\left(10 \mathrm{mg} \mathrm{kg}^{-1}\right)(\mathrm{HN}$ $60: 2004)$. Pollution with $\mathrm{Sb}$ was reported in shooting range areas. It is known that $\mathrm{Sb}$ is more mobile compared to $\mathrm{Pb}$. Therefore, shooting ranges can have larger long-term environmental problem related to groundwater pollution (Shtangeeva et al. 2011). The suppression of shoot and root biomass under an increase of antimony concentration could result from plant $\mathrm{Sb}$ accumulation. Under our circumstances, both shoot and root systems of plant grown in the most contaminated soil accumulated significantly higher concentration of antimony and growth of these plants was inhibited. Studies show that environmental stressors, such as heavy metals, can disturb plant growth and development (Yazdi et al. 2019). This study revealed that above-ground and below-ground plant growth was negatively affected by heavily contaminated $(\mathrm{Pb}, \mathrm{Sb})$ shooting range soil. Numerous studies show that the reduction of root length in the presence of heavy metals appears as the reason for metal interference with the process of cell division, which causes chromosomal aberration and abnormal mitosis (Yazdi et al. 2019).

Accumulation of heavy metals in the tissues of exposed plants depends on metal supply and plant species. Plants can absorb heavy metals through passive transport by water mass flow or through active transport by the plasma membrane of the root cell (Midhat et al. 2019). During this study lead was the main contaminant in soil. In the most contaminated site of the shooting range, roots of $L$. sativa accumulated almost 10 times more $\mathrm{Pb}$ compared to shoots. $\mathrm{Pb}$ content was also higher in roots 
compared to leaves of the Brassica campestris seedlings (Zhang et al. 2020). In the case of Ni, Zhao et al. (2019) reported higher concentration in roots than shoots. Our results agree in the most Nicontaminated site; Ni concentration in L. sativa roots were significantly higher. The tendency of higher heavy metal accumulation in roots than shoots were also reported in other studies (Zhao et al. 2019; Steliga and Kluk 2020). The roots are the main organ of the plant for stabilization and collection of nutrients (Steliga and Kluk 2020). Translocation from roots to shoot might be limited by precipitation of heavy metals on the root membrane. This barrier could control metal mobility from root to shoot (Shtangeeva et al. 2011). In terms of BF, results concerning BF' of $\mathrm{Cu}$ and $\mathrm{Ni}$ in plants from the most contaminated site stand out. In the 5-30 m area of the shooting range, BFs were very low. However, in $L$. sativa, exposed to the most contaminated $\mathrm{BF}$ can be put together in the following sequence: $\mathrm{Sb}<\mathrm{Fe}<\mathrm{Pb}$ $<\mathrm{Mn}<\mathrm{Zn}<\mathrm{Ni}<\mathrm{Cu}$, but only BF of $\mathrm{Cu}, \mathrm{Fe}$, and $\mathrm{Ni}$ were significantly higher. Very low $\mathrm{Pb}$ bioaccumulation could be explained by low concentration of soluble $\mathrm{Pb}$ in soil; as the $\mathrm{pH}$ and organic matter values of studied soil do not drastically change the solubility of $\mathrm{Pb}$ (Ashworth and Alloway 2008; Lewińska and Karczewska 2019). Similar results reported (Dradrach et al. 2020) with bioaccumulation of As in Festuca rubra L. values of TF confirm better translocation from "soil to root" system than "root to shoot" at translocation of $\mathrm{Cu}, \mathrm{Fe}, \mathrm{Ni}$ and $\mathrm{Pb}$. $\mathrm{TF}_{\text {soil to root }}$ of $\mathrm{Cu}$ and $\mathrm{Pb}$ (in all test samples) and $\mathrm{Ni}(45 \mathrm{~m})>1$ shows that metals absorbed by Lactuca sativa are accumulated in its root tissue first and poorer metal translocation in shoots was visible, except for Mn.

\section{Conclusions}

The present study demonstrated physicochemical properties and phytotoxicity of the shooting range soil. The shooting range soil was site-specific with high contamination in $\mathrm{Pb}$ and $\mathrm{Sb}$. A high concentration of antimony, which is more mobile in the soil than lead, in the most contaminated site of the range revealed that pollution of shooting range still needs better understanding and approaches for remediation of these sites must be considered to avoid its hazardous leaching into groundwater. Our results showed that in the most contaminated site, the inhibition of tested plant growth was observed. Translocation of heavy metals from root to shoot was suppressed, and to our knowledge, this could be caused by very extreme heavy metal concentrations when heavy metals on the root membrane form a barrier that controls metal mobility from root to shoot.

\section{Declarations}

\section{Acknowledgements}

The studies were performed using the equipment of the Department of Environmental Science of Vytautas Magnus University and Lithuanian Energy Institute.

\section{References}


1. Ahmad M, Soo Lee S, Yang JE et al (2012) Effects of soil dilution and amendments (mussel shell, cow bone, and biochar) on $\mathrm{Pb}$ availability and phytotoxicity in military shooting range soil. Ecotoxicol Environ Saf 79:225-231. https://doi.org/10.1016/j.ecoenv.2012.01.003

2. Ahmad MSA, Ashraf M (2012) Essential roles and hazardous effects of nickel in plants. In: Rev Environ Contam Toxicol. pp 125-167

3. Ashraf U, Mahmood MH-R, Hussain S et al (2020) Lead (Pb) distribution and accumulation in different plant parts and its associations with grain $\mathrm{Pb}$ contents in fragrant rice. Chemosphere 248:126003. https://doi.org/10.1016/j.chemosphere.2020.126003

4. Ashworth DJ, Alloway BJ (2008) Influence of dissolved organic matter on the solubility of heavy metals in sewage-sludge-amended soils. Commun Soil Sci Plant Anal 39:538-550. https://doi.org/10.1080/00103620701826787

5. Barker AJ, Mayhew LE, Douglas TA et al (2020) Lead and antimony speciation associated with the weathering of bullets in a historic shooting range in Alaska. Chem Geol 553:119797. https://doi.org/10.1016/j.chemgeo.2020.119797

6. Boquete MT, Lang I, Weidinger $M$ et al (2021) Patterns and mechanisms of heavy metal accumulation and tolerance in two terrestrial moss species with contrasting habitat specialization. Environ Exp Bot 182:104336. https://doi.org/10.1016/j.envexpbot.2020.104336

7. Carreras HA, Rodriguez JH, González CM et al (2009) Assessment of the relationship between total suspended particles and the response of two biological indicators transplanted to an urban area in central Argentina. Atmos Environ 43:2944-2949. https://doi.org/10.1016/j.atmosenv.2009.02.060

8. Dinake P, Maphane O, Sebogisi K et al (2018) Pollution status of shooting range soils from $\mathrm{Cd}, \mathrm{Cu}$, $\mathrm{Mn}, \mathrm{Ni}$ and $\mathrm{Zn}$ found in ammunition. Cogent Environ Sci 4:1528701. https://doi.org/10.1080/23311843.2018.1528701

9. Dradrach A, Karczewska A, Szopka K (2020) Arsenic accumulation by red fescue (Festuca rubra) growing in mine affected soils - Findings from the field and greenhouse studies. Chemosphere 248:126045. https://doi.org/10.1016/j.chemosphere.2020.126045

10. Duan D, Tong J, Xu Q et al (2020) Regulation mechanisms of humic acid on Pb stress in tea plant (Camellia sinensis L.). Environ Pollut 267:115546. https://doi.org/10.1016/j.envpol.2020.115546

11. Fayiga AO, Saha UK (2016) Soil pollution at outdoor shooting ranges: Health effects, bioavailability and best management practices. Environ Pollut 216:135-145.

https://doi.org/10.1016/j.envpol.2016.05.062

12. Gul I, Manzoor M, Kallerhoff J, Arshad M (2020) Enhanced phytoremediation of lead by soil applied organic and inorganic amendments: $\mathrm{Pb}$ phytoavailability, accumulation and metal recovery. Chemosphere 258:127405. https://doi.org/10.1016/j.chemosphere.2020.127405

13. Hadi F, Aziz T (2015) A Mini Review on Lead (Pb) Toxicity in Plants. J Biol Life Sci 6:91. https://doi.org/10.5296/jbls.v6i2.7152

14. Johnsen IV, Aaneby J (2019) Soil intake in ruminants grazing on heavy-metal contaminated shooting ranges. Sci Total Environ 687:41-49. https://doi.org/10.1016/j.scitotenv.2019.06.086 
15. Kumarathilaka P, Ahmad M, Herath I et al (2018) Influence of bioenergy waste biochar on proton- and ligand-promoted release of $\mathrm{Pb}$ and $\mathrm{Cu}$ in a shooting range soil. Sci Total Environ 625:547-554. https://doi.org/10.1016/j.scitotenv.2017.12.294

16. Lewińska K, Karczewska A (2019) A release of toxic elements from military shooting range soils as affected by $\mathrm{pH}$ and treatment with compost. Geoderma 346:1-10. https://doi.org/10.1016/j.geoderma.2019.03.031

17. Lewis L, Poppenga R, Davidson W, Fischer JR, Morgan KA (2001) Lead toxicosis and trace element levels in wild birds and mammals at a firearms training facility. Arch Environ Contam Toxicol 41:208-214. https://doi.org/10.1007/s002440010239

18. Manninen S, Tanskanen N (1993) Transfer of lead from shotgun pellets to humus and three plant species in a Finnish shooting range. Arch Environ Contam Toxicol 24:410-414. https://doi.org/10.1007/BF01128741

19. Ma WC (1989) Effect of soil pollution with metallic lead pellets on lead bioaccumulation and organ/body weight alterations in small mammals. Arch Environ Contam Toxicol 18:617-622. https://doi.org/10.1007/BF01055030

20. Midhat L, Ouazzani N, Hejjaj A et al (2019) Accumulation of heavy metals in metallophytes from three mining sites (Southern Centre Morocco) and evaluation of their phytoremediation potential. Ecotoxicol Environ Saf 169:150-160. https://doi.org/10.1016/j.ecoenv.2018.11.009

21. Moon DH, Cheong KH, Khim J et al (2011) Stabilization of Cu-contaminated army firing range soils using waste oyster shells. Environ Geochem Health 33:159-166. https://doi.org/10.1007/s10653010-9358-y

22. Moreira IN, Martins LL, Mourato MP (2020) Effect of Cd, Cr, Cu, Mn, Ni, Pb and Zn on seed germination and seedling growth of two lettuce cultivars (Lactuca sativa L.). Plant Physiol Rep 25:347-358. https://doi.org/10.1007/s40502-020-00509-5

23. OECD/OCDE 208 (2006) Terrestrial Plant Test: Seedling Emergence and Seedling Growth Test. OECD Guidelines for the Testing of Chemicals

24. Ogawa S, Katoh M, Sato T (2015) Simultaneous lead and antimony immobilization in shooting range soil by a combined application of hydroxyapatite and ferrihydrite. Environ Technol 36:26472656. https://doi.org/10.1080/09593330.2015.1042071

25. Rehman AU, Nazir S, Irshad R et al (2021) Toxicity of heavy metals in plants and animals and their uptake by magnetic iron oxide nanoparticles. J Mol Liq 321:114455.

https://doi.org/10.1016/j.molliq.2020.114455

26. Rodríguez-Seijo A, Lago-Vila M, Andrade ML, Vega FA (2016) Pb pollution in soils from a trap shooting range and the phytoremediation ability of Agrostis capillaris L. Environ Sci Pollut Res 23:1312-1323. https://doi.org/10.1007/s11356-015-5340-7

27. Sanderson P, Naidu R, Bolan N (2014) Ecotoxicity of chemically stabilised metal(loid)s in shooting range soils. Ecotoxicol Environ Saf 100:201-208. https://doi.org/10.1016/j.ecoenv.2013.11.003 
28. Sanderson P, Qi F, Seshadri B et al (2018) Contamination, Fate and Management of Metals in Shooting Range Soils-a Review. Curr Pollut Rep 4:175-187. https://doi.org/10.1007/s40726-0180089-5

29. Shtangeeva I, Bali R, Harris A (2011) Bioavailability and toxicity of antimony. J Geochem Explor 110:40-45. https://doi.org/10.1016/j.gexplo.2010.07.003

30. Siebielec G, Chaney RL (2012) Testing amendments for remediation of military range contaminated soil. J Environ Manage 108:8-13. https://doi.org/10.1016/j.jenvman.2012.04.028

31. Steliga T, Kluk D (2020) Application of Festuca arundinacea in phytoremediation of soils contaminated with $\mathrm{Pb}, \mathrm{Ni}, \mathrm{Cd}$ and petroleum hydrocarbons. Ecotoxicol Environ Saf 194:110409. https://doi.org/10.1016/j.ecoenv.2020.110409

32. Ullah R, Muhammad S (2020) Heavy metals contamination in soils and plants along with the maficultramafic complex (Ophiolites), Baluchistan, Pakistan: Evaluation for the risk and phytoremediation potential. Environ Technol Innov 19:100931. https://doi.org/10.1016/j.eti.2020.100931

33. Urrutia-Goyes R, Mahlknecht J, Argyraki A, Ornelas-Soto N (2017) Trace element soil contamination at a former shooting range in Athens, Greece. Geoderma Reg 10:191-199. https://doi.org/10.1016/j.geodrs.2017.08.002

34. Yadav SK (2010) Heavy metals toxicity in plants: An overview on the role of glutathione and phytochelatins in heavy metal stress tolerance of plants. S Afr J Bot 76:167-179. https://doi.org/10.1016/j.sajb.2009.10.007

35. Yazdi M, Kolahi M, Mohajel Kazemi E, Goldson Barnaby A (2019) Study of the contamination rate and change in growth features of lettuce (Lactuca sativa Linn.) in response to cadmium and a survey of its phytochelatin synthase gene. Ecotoxicol Environ Saf 180:295-308. https://doi.org/10.1016/j.ecoenv.2019.04.071

36. Zhang H, Zhang L-L, Li J et al (2020) Comparative study on the bioaccumulation of lead, cadmium and nickel and their toxic effects on the growth and enzyme defence strategies of a heavy metal accumulator, Hydrilla verticillata (L.f.) Royle. Environ Sci Pollut Res 27:9853-9865. https://doi.org/10.1007/s11356-019-06968-0

37. Zhang $\mathrm{Y}$, Zhang $\mathrm{H}$, Zhang $\mathrm{Z}$ et al (2018) pH effect on heavy metal release from a polluted sediment. J Chem 2018:1-7. https://doi.org/10.1155/2018/7597640

38. Zhao J, Lu C, Tariq M et al (2019) The response and tolerance mechanisms of lettuce (Lactuca sativa L.) exposed to nickel in a spiked soil system. Chemosphere 222:399-406. https://doi.org/10.1016/j.chemosphere.2019.01.119

\section{Tables}

Due to technical limitations, the tables are only available as a download in the supplemental files section.

\section{Figures}



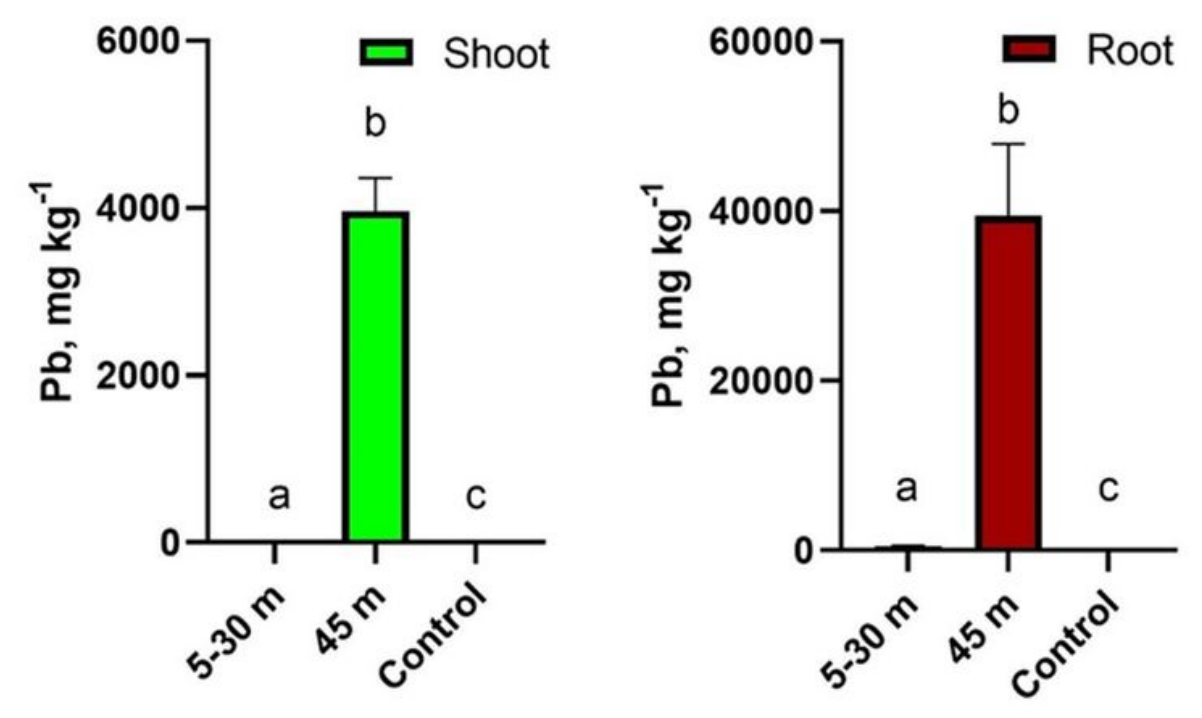

Figure 1

Concentration of lead (mg kg-1) in the shoot and root of Lactuva sativa exposed to shooting range soils. Values are means \pm standard error. The different letters indicate significant difference $(p>0.05)$ between the treatments $(U$ test). 

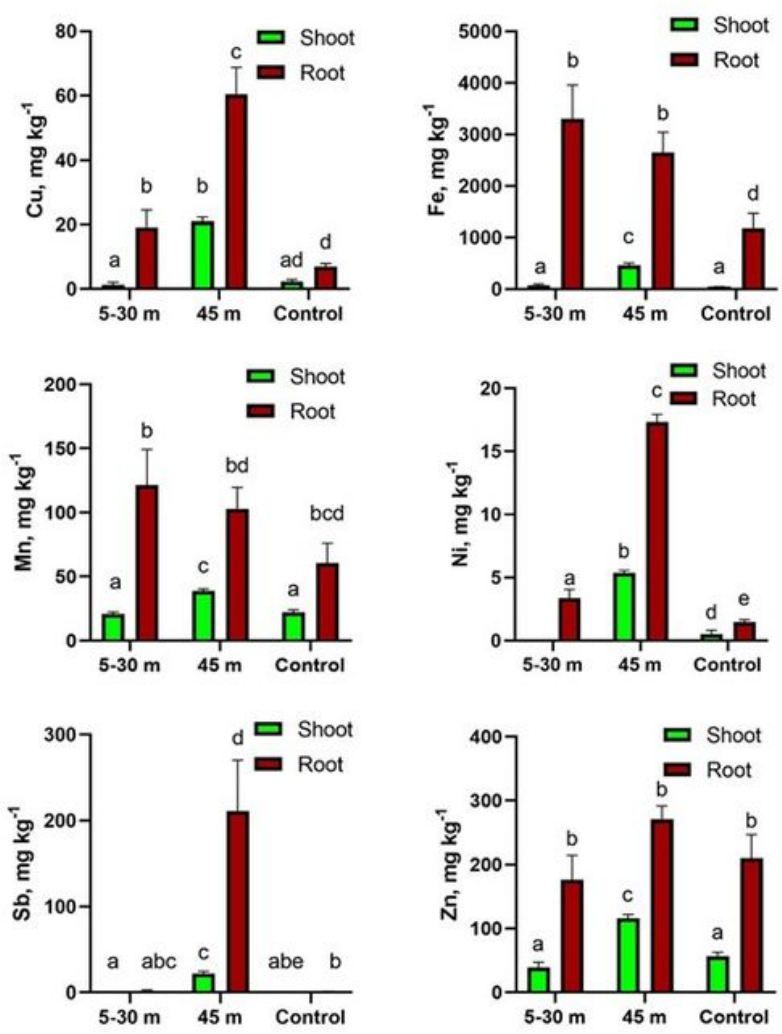

\section{Figure 2}

Concentration (mg kg-1) of $\mathrm{Cu}, \mathrm{Fe}, \mathrm{Mn}, \mathrm{Ni}, \mathrm{Sb}$ and $\mathrm{Zn}$ in the shoot and root of Lactuva sativa exposed to the shooting range soil. Values are means \pm standard error. Different letters indicate statistically significant difference between the treatments $(U$ test, $p<0.05)$. 

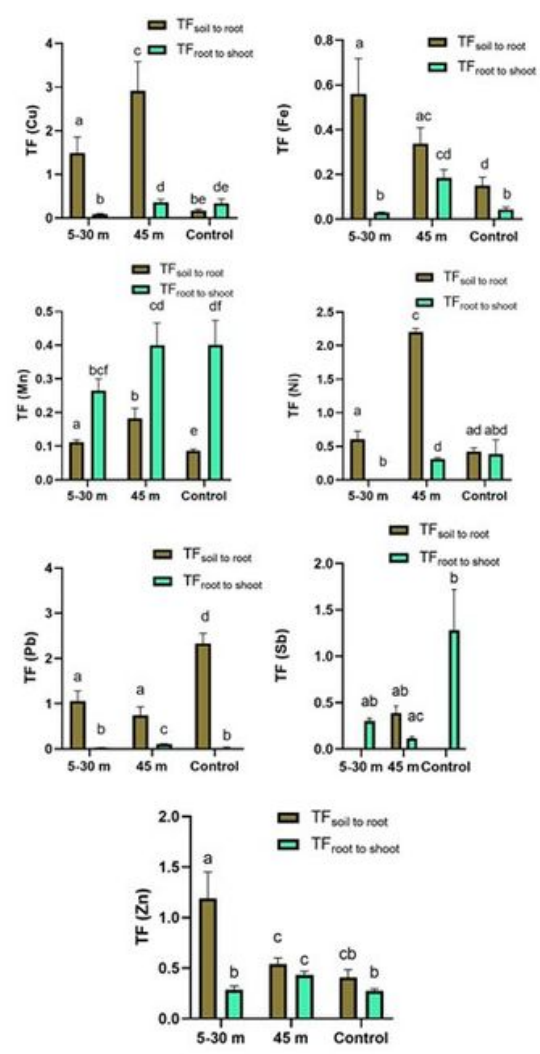

\section{Figure 3}

Translocation factor (TFsoil to root; TFroot to shoot) of $\mathrm{Cu}, \mathrm{Fe}, \mathrm{Mn}, \mathrm{Ni}, \mathrm{Pb}, \mathrm{Sb}$, and $\mathrm{Zn}$ of Lactuva sativa exposed to shooting range soils. Values are means \pm standard error. Different letters above the bars indicate significant difference between the treatments $(U$ test, $p<0.05)$.

\section{Supplementary Files}

This is a list of supplementary files associated with this preprint. Click to download.

- Tables.docx 